IRA-International Journal of Education \& Multidisciplinary Studies

ISSN 2455-2526; Vol.12, Issue 02 (August, 2018)

Pg. no. 30-39.

Institute of Research Advances

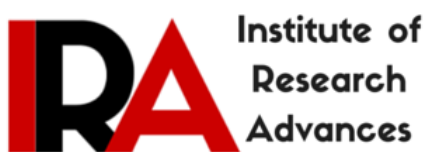

http://research-advances.org/index.php/IJEMS

\title{
Gender Disparities at Higher Education in Kenya: A Case of Moi University
}

Joash A. Migosi

Lecturer, University of Nairobi, PO BOX 30197 - 00100, Nairobi, Kenya.

Type of Review: Peer Reviewed.

DOl: http://dx.doi.org/10.21013/jems.v12.n2.p1

How to cite this paper:

Migosi, J.A. (2018). Gender Disparities at Higher Education in Kenya: A Case of Moi University. IRA International Journal of Education and Multidisciplinary Studies (ISSN 2455-2526), 12(2), 3039.doi: http://dx.doi.org/10.21013/jems.v12.n2.p1

(C) Institute of Research Advances.

\section{(c) EY-NC}

This work is licensed under a Creative Commons Attribution-Non Commercial 4.0 International License subject to proper citation to the publication source of the work.

Disclaimer: The scholarly papers as reviewed and published by the Institute of Research Advances (IRA) are the views and opinions of their respective authors and are not the views or opinions of the IRA. The IRA disclaims of any harm or loss caused due to the published content to any party.

Institute of Research Advances is an institutional publisher member of Publishers Inter Linking Association Inc. (PILA-CrossRef), USA. The institute is an institutional signatory to the Budapest Open Access Initiative. Hungary advocating the open access of scientific and scholarly knowledge. The Institute is a registered content provider under Open Access Initiative Protocol for Metadata Harvesting (OAI-PMH).

The journal is indexed \& included in WorldCat Discovery Service (USA), CrossRef Metadata Search (USA), WorldCat (USA), OCLC (USA), Open J-Gate (India), EZB (Germany) Scilit (Switzerland), Airiti (China), Bielefeld Academic Search Engine (BASE) of Bielefeld University, Germany, PKP Index of Simon Fraser University, Canada. 


\begin{abstract}
The purpose of this study was to understand the gender representation in higher education in Kenya, particularly at the Moi University in Eldoret, Kenya. The study was carried out in the 1995/96 academic year and focused on selected faculties and schools in regard to gender disparities in University enrolment at undergraduate level. Proportionate random sampling technique was employed in identifying the respondents to this study. The questionnaire and document analysis guide were the key instruments used in this study. For secondary data, the study used Document Analysis Guide which was used to collect data from the university authorities and the Ministry of Education Statistics Division and number of candidates who sat for Kenya Certificate for Secondary Education in the years 1990-93. Primary data was collected by questionnaires. The questionnaire return rate was $70 \%$. This return rate was therefore considered sufficient to provide the required information. Data from the questionnaire and the Document Analysis Guide were analyzed using descriptive statistics. Gender representation data was analysed per faculty. Findings from the study indicated revealed that female student enrolment at Moi University is quite low compared to male enrolment. The most affected faculties are Wildlife Management and Technology and Forestry Resources represented by $6.38 \%$ and $13.4 \%$ respectively. Other Science based courses had at least more than $20 \%$ of the female student representation. Even in the arts based faculties, parity is far from being achieved. This calls for concerted efforts to increase the female student enrolment at the university level in Kenya particularly in the fields of Science and Technology.
\end{abstract}

Key words: Gender Disparities, Higher Education, Kenya, Moi University

\title{
Introduction
}

Globally, there is an interest in understanding performance in any area structured along gender. This undertaking is deliberate in trying to understand and remind populace that gender is critical in realizing all developmental targets set. It is against this background that this study attempted to understand the university gender representation higher education in Kenya, specifically in Moi University. Husen (1987:20) notes that one of the results expected from the expansion in higher education is the reduction of inequalities of opportunity in all fields. Although the female share of higher education enrolment increased from 32 percent in 1960 to 41 percent in 1992 in the world as a whole, this increase has since stagnated. The developing countries have done well as the industrialized countries in increasing the female share of total higher education enrolment: there are 11 percentage points of increase for both during the period 1960-1982. This means that the difference between the female participation rates in developing and industrialized countries has remained the same during this period.

Studies carried out in Elsalvador reveal that female enrolment had at some periods overtaken that of male. In 1975, the gross enrolment ratio in the seven to fifteen age group for males was 76 rising only to 77 by 1987. Female enrolment percentage overtook that of males rising from 73 to 81 (Unesco, 1989).

Graham - Brown (1991) notes that in Nicaragua, although enrolments rose for both sexes between 1974 and 1987, female enrolment overtook male. In this case, the government took clear initiative to promote education for boys after 1979. But both conscription into the army during the contra war and poverty, the tendency for boys to start working while young were also part of the reason (Graham Brown, 1991).

In Botswana and Lesotho, girls outnumber boys at the lower end of the educational spectrum, and even at secondary and university level the numbers of women are substantial, compared with most neighbouring countries. This is a historical trend due to the nature of the traditional cattle-rearing economy (Graham Brown, 1991).

Hughes and Mwiria (1988) observe that as is the case throughout Sub-Saharan Africa, women are dramatically under-presented in Kenyan Higher Education. Although the participation gap narrowed slowly in the 1970s, the 1980s have produced no changes. Since 1981, roughly 30 per cent of University students have been female. Maliyamkono, et al (1982:135), observe that of the as many as 9,000 Kenyan studying abroad, data suggests that roughly 11 percent of those were female. These rates are strongly affected by the retention of women at lower levels of education. Kinyanjui (1975) noted that, "As girls ascend from one level of education to another, their proportion of the total enrolment decreases by 10 per cent".

In 1986, women comprised 48 per cent of primary school students, 41 per cent of secondary school students, but only 30 per cent of university students (Republic of Kenya, 1988, 148-9). There are many reasons why women are relegated to lower representation in the education system. The reasons for this poor performance have been 
well documented. For example, women have attended poor quality schools in disproportionately high numbers (Smock, 1977; Kinyanjui,1987); have less access to a broad range of curricula particularly in the sciences (Smock, 1977) and are conditioned by biased learning materials and classroom dynamics (Obura, 1986; Owino, 1987).

Perhaps most critical in this attrition of female students, are decisions made at the level of the individual family (Brokensha, 1973). As long as resources are scarce, the potential return to a family's investment decision continues to be more likely to have a greater impact if a son is educated (Mbilinyi, 1973; Smock 1977:40; Bowman and Anderson, 1980; Kinyanjui, 1981; Mwiria, 1985; World Bank, 1988). In addition, in a patrilineal society, parents have a "greater claim on sons' income than on daughters"” (Smock 1977:40). Brokensha (1973) suggests that in some rural settings parents fear that schooling will make their daughters discontent and even immoral. Parents of Swahili women are concerned about the compromises modern education may promote in their cultural and religious integrity (Potert, 1988). In other cases, marriage may intervene (Ponsi, 1988).

The net result of this plethora of economic and cultural barriers is that women reach the highest levels of education in Kenya in very small numbers. This study has not looked at causes of gender disparities but has given the picture of representation at Moi University. Other studies done indicate that these broad participation rates hide even greater variation when enrolment is examined at the level of the individual faculty. For example, between 1976 and 1987, women never constituted more than 51 of the total Bachelor of Science enrolment or 4 per cent of the engineering enrolment. The poor representation of women in the sciences begins long before university. Eshiwani (1995) reported the extremely high negative perceptions that secondary school girls have of science based careers such as engineering, dentistry, and agriculture. Such perceptions have persisted over the years as shown in Table 1

Table 1: $\quad$ Proportion of Women doing selected Undergraduate Subjects in Kenya between 1976 and 1988.

\begin{tabular}{|l|l|l|l|l|l|l|l|l|l|}
\hline Year & B.Ed* & $\begin{array}{l}\text { B.Ed } \\
(\mathrm{HS})^{* *}\end{array}$ & Science & Arts & Commerce & Engineering & Medicine & $\begin{array}{l}\text { Agricu } \\
\text { lture }\end{array}$ & \begin{tabular}{l} 
Law \\
\hline $1976 / 77$
\end{tabular} \\
\hline 33 & - & 15 & 28 & 18 & 1 & 15 & 17 & 24 \\
\hline $1977 / 78$ & 31 & - & 11 & 35 & 20 & 2 & 11 & 21 & 30 \\
\hline $1978 / 79$ & 33 & - & 14 & 43 & 19 & 2 & 20 & 27 & 32 \\
\hline $1979 / 80$ & 38 & - & 11 & 39 & 28 & 2 & 22 & 22 & 33 \\
\hline $1980 / 81$ & 43 & - & 11 & 37 & 30 & 2 & 21 & 21 & 36 \\
\hline $1981 / 82$ & 47 & - & 13 & 37 & 32 & 1 & 20 & 20 & 41 \\
\hline $1983 / 84$ & 48 & 98 & 12 & 35 & 34 & 2 & 20 & 18 & 41 \\
\hline $1984 / 85$ & 46 & 98 & 12 & 33 & 33 & 2 & 21 & 21 & 38 \\
\hline $1985 / 86$ & 46 & 89 & 11 & 28 & 27 & 2 & 20 & 23 & 40 \\
\hline $1986 / 87$ & 46 & 86 & 13 & 31 & 25 & 4 & 21 & 20 & 41 \\
\hline $1987 / 88$ & 44 & 90 & 15 & 31 & 24 & 3 & 21 & 19 & 43 \\
\hline
\end{tabular}

Source: Republic of Kenya, 1977 - 1988

*This figure combines students receiving a B.Ed (Arts) and those receiving B.Ed (Science) degrees.

Men and women participate in very different proportions in these two programmes as can be seen in Table 2. This table shows that the number of women students taking B.Ed (Arts) has continued to reduce between 1985 and 1988 whereas the number of female students taking B.Ed. (science) has been on the rise.

Table 2: Percentage of Women enrolled in the B.Ed (Science) and B.Ed (Arts) Programs between 1985 and 1988

\begin{tabular}{|l|l|l|}
\hline Year & B.Ed (Science) & B.Ed (Arts) \\
\hline $1985-1986$ & $24 \%$ & $58 \%$ \\
\hline $1986-1987$ & $26 \%$ & $57 \%$ \\
\hline & $25 \%$ & $52 \%$ \\
\hline
\end{tabular}

Source; Economic Survey 1988 
Table 3: Percentage of University Enrolment in Kenya 1965-1988.

\begin{tabular}{|l|l|l|}
\hline Year & Male & Female \\
\hline $1965 / 66$ & 78.7 & 21.3 \\
\hline $1968 / 70$ & 83.9 & 16.1 \\
\hline $1972 / 73$ & 84.0 & 16.0 \\
\hline $1976 / 77$ & 79.6 & 20.4 \\
\hline $1977 / 78$ & 79.0 & 21.4 \\
\hline $1978 / 79$ & 74.9 & 25.1 \\
\hline $1979 / 80$ & 72.2 & 26.7 \\
\hline $1980 / 81$ & 73.3 & 27.8 \\
\hline $1981 / 82$ & 70.2 & 29.6 \\
\hline $1983 / 84$ & 68.0 & 32.0 \\
\hline $1984 / 85$ & 68.7 & 31.3 \\
\hline $1985 / 86$ & 70.3 & 29.7 \\
\hline $1986 / 87$ & 70.3 & 29.7 \\
\hline $1987 / 88$ & 70.2 & 29.8 \\
\hline
\end{tabular}

Source: Economic Survey 1988

Table 3 gives an interesting revelation concerning university enrolment in Kenya. Basically, the table shows a decreasing intake for male students and an increase in the female intakes. This may be attributed to a greater awareness on the value of the education of the girl child in the county and the establishment of more schools for the girls. If this scenario is left to continue, then sooner or later the enrolment for both male and female students at the university may be at parity.

Table 4: Proportion of Women doing selected Undergraduate Subjects in Kenya between 1976 and 1988.

\begin{tabular}{|l|l|l|l|l|l|l|l|l|l|}
\hline Year & B.Ed* & $\begin{array}{l}\text { B.Ed } \\
(\mathrm{HS})^{* *}\end{array}$ & Science & Arts & Commerce & Engineering & Medicine & Agriculture & Law \\
\hline $1976 / 77$ & 33 & - & 15 & 28 & 18 & 1 & 15 & 17 & 24 \\
\hline $1977 / 78$ & 31 & - & 11 & 35 & 20 & 2 & 11 & 21 & 30 \\
\hline $1978 / 79$ & 33 & - & 14 & 43 & 19 & 2 & 20 & 27 & 32 \\
\hline $1979 / 80$ & 38 & - & 11 & 39 & 28 & 2 & 22 & 22 & 33 \\
\hline $1980 / 81$ & 43 & - & 11 & 37 & 30 & 2 & 21 & 21 & 36 \\
\hline $1981 / 82$ & 47 & - & 13 & 37 & 32 & 1 & 20 & 20 & 41 \\
\hline $1983 / 84$ & 48 & 98 & 12 & 35 & 34 & 2 & 20 & 18 & 41 \\
\hline $1984 / 85$ & 46 & 98 & 12 & 33 & 33 & 2 & 21 & 21 & 38 \\
\hline $1985 / 86$ & 46 & 89 & 11 & 28 & 27 & 2 & 20 & 23 & 40 \\
\hline $1986 / 87$ & 46 & 86 & 13 & 31 & 25 & 4 & 21 & 20 & 41 \\
\hline $1987 / 88$ & 44 & 90 & 15 & 31 & 24 & 3 & 21 & 19 & 43 \\
\hline
\end{tabular}

Source: Republic of Kenya, 1977 - 1988

*This figure combines students receiving a B.Ed (Arts) and those receiving B.Ed (Science) degrees. ** B.Ed (HS) Bachelor of Education Home Science

Table 4 suggests that women have tended to pursue law, teaching and arts subjects over science, engineering, agriculture and medicine. Between 1980 and 1987, degrees in education and arts alone, accounted for between 63.7 and 67.6 per cent respectively of the total women enrolment in Kenya. 
Table 5: First year undergraduate enrollment in public universities in Kenya 1990/91-1991/92

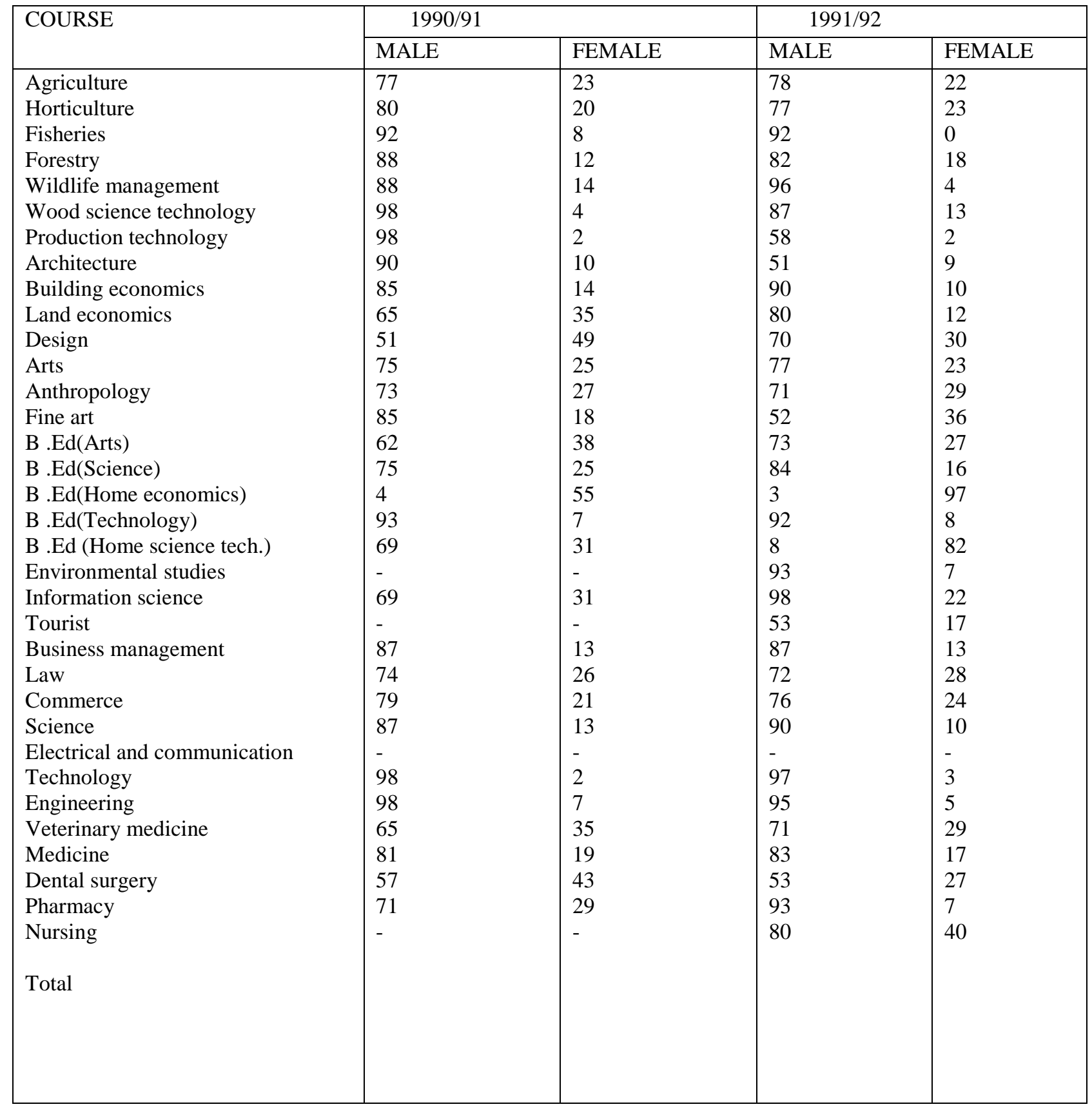

Source: Economic Survey, 1993

- Provisional

- Includes courses on food science and technology, range management and applied agricultural studies.

- Includes civil, mechanical, electrical, agricultural and building construction.

N/B Conversion into percentages my own 
Table 5 suggest that in more recent years, women have tended to pursue B.Ed (Science), B.Ed (Arts), Information Science, Veterinary Medicine and Dental Surgery in big numbers. However, women are still underrepresented in most courses particularly those that require a background in science and Mathematics.

A study by Eshiwani (1983a) revealed that 52.2 per cent of the university students taking bachelor of education course at Kenyatta University in 1983 were male while 45.5 per cent were female. This tendency towards parity might have been due to the nature of the course offered, that is, Bachelor of Education.

Unicef (1984:68) points out that Kenyan girls chances of having secondary schools to attend depend, more than boys on the socio-economic development of their communities. This means a higher socio-economic community will send their daughters to school in bigger numbers than the lower socio-economic communities.

Eshiwani (1983b) conducted a study of women's access to higher education in Kenya with special reference to Mathematics and Science Education. The purpose of this study was to investigate the women's access to higher education in Kenya, especially in the area of Science and mathematics education. Data for this study was collected in three phases over a period of 18 moths. The first phase consisted of a study of enrolment records from the Ministry of Basic Education, Ministry of Higher Education and the University of Nairobi. Enrolment records for males and females at primary level, secondary level and university level respectively were considered. He second phase of the study consisted of administering a questionnaire to head teachers in 40 secondary schools with sixth form. The information on this questionnaire included facilities for Science and Mathematics teaching, the provision, qualification and experience of science teachers. The third phase consisted of interview schedules with selected women students studying science and science based subjects at the university of Nairobi and Kenyatta university college. Results of this study showed that women were underrepresented in education in Kenya at all levels especially in higher education. The studies also showed that women in Kenya were under-represented and are under-achievers in Science and Mathematics Education. The study made the following recommendations; more secondary schools for girls, Girls technical schools, a model Science Academy for girls, compensatory enrolment for girls and role models for girls. The present study has gone on to investigate not only gender representation at the university level, but also region and socio-economic background of university students at the university level.

Nginye (1996) conducted a study on the equity in enrolment by gender and administrative divisions in Kirinyaga District. The purpose of the study was to investigate the extent to which equity in the distribution of primary school opportunities by gender and administrative divisions has been achieved. The causes of disparities in access to primary education were examined. Information on the causes of disparities in distribution of educational opportunities was collected from a sample of 56 primary school heads in the study area. A questionnaire was employed to collect data from the teachers and descriptive statistics were used to analyze the data. Causes of the poor disparities were classified as those of non-enrolment and those of the poor retention rates within the education system. The equity poor inequity of the distribution of educational opportunity as measured by the enrolment was analyzed by use of the curve of concentration (Lorenz curve) and Gini's coefficient. The findings of the study suggested that although inequalities in the distribution of educational opportunities exist, the extent was low. Other findings were, Mwea Division was more disadvantaged, and girl's enrolment was more inequitable than that of boys, the factors explaining non-enrolment also explained school dropout cases. The present study looks not only at equity in university enrolment by gender and regions but also socio-economic status of the students. It goes further in looking at the disparities at the national level.

The data reported here was collected from the Moi University's student registry office and Maseno University College. The [purpose of this sub-section was to find out how gender is represented at the faculty level.

\section{Methodology}

The population studied was drawn from all faculties/schools at Moi university Main campus, Chepkoilel Campus, Faculty of Health Sciences and Maseno University College, that is, School of Social, Cultural and Development Studies, Faculties of Technology, Information Sciences, Forestry and Wildife Management, Science, Health Sciences, Law and Education. The study was restricted to the undergraduate students in all years of study during the 1995/96 academic year of study.

Proportionate random sampling technique was employed in identifying the rspondents to this study. According to this technique, each faculty/school in Moi University was represented in exact proportion to its student enrolment. Due to the large number of population, 10 percent of the total enrolments in each Faculty/School were considered for the study except the Faculty of Law which is considered $26 \%$ of the students due to the low enrolment in the faculty. This ratio was considered appropriate in social sciences (Kerlinger, 1973). 
The questionnaire and document analysis guide were the key instruments used in this study.The Questionnaire was prepared by the researcher and contained items seeking information on the enrolment in the university by region, gender and socio-economic background. The construction of the questionnaire items was based on the information gathered during the literature review. The literature helped to identify the items that could lead to determining the socio-economic background of the students.

The questionnaire as an instrument was chosen because it was possible to reach many respondents. The instrument also offered the respondents an opportunity to freely express themselves in an impersonal atmosphere without the face to face embarrassment, particularly when they required responding to the item on home background.

The test-retest method was used in determining the reliability of the questionnaire. The questionnaire was administered to the same students used in the pilot study within an interval of one week. The responses to the items on the questionnaire were assigned numerical scores. The Pearson product moment correlation coefficient was worked out to give $r=0.74$. This was considered enough measure to make the instrument reliable (Kerlinger, 1973).

For secondary data, the researcher developed a proforma (Document Analysis Guide) which was used to collect data from the university authorities and the Ministry of Education Statistics Division, number of candidates KCSE 1990-93. The data collected included: the total university intakes in the last five years, enrolment by sex, enrolment by faculty/school and home provinces districts of the students.

A letter of introduction was attached to each questionnaire, stating clearly the purpose of the study. The questionnaires were given out to 822 sampled students using research assistants who were picked from each faculty/school and well trained on the exercise. The research assistants were quite familiar with their fellow students and therefore it was better to use them. The questionnaires were administered to the students and were requested to return the filled questionnaires to the research assistants. Some cases where the sampled students took long to return the questionnaires, the research assistants made a follow up to collect them from the students. The return rate of the questionnaires was $70 \%$. This was calculated from the number of questionnaires administered (822). This return rate was therefore considered sufficient to provide the required information. The questionnaire was subdivided into two sections. Section: A" sought information on the students personal background and section "B" sought information on the family's socio-economic background.

A proforma seeking information from the university was given to the officers in charge of student registry (Admissions) by the researcher. The officers provided the information that was sought in regard to student distribution in faculties, students' gender and districts and provinces of origin.

Data from the questionnaire and the proforma were analyzed using descriptive statistics. Data on regional disparities was analyzed using Lorenz curve and its related Gini's coefficient and coefficients of equality. The total number of students who sat for "O" level Examinations (1990-1993 cohorts) formed the total population for this study while the number which actually made it to Moi University was considered as the enrolment.

\section{Findings}

\section{Gender Representation in the Faculty of Education}

This faculty had the arts class only until 1989 when the Education Technology was introduced. Education (Science) and education (Home Science) were introduced in the subsequent years. For the purpose of this study, this faculty has been subdivided into education science and education arts. Education science shall comprise of education technology, education, science and education home science.

In the 1993/94 academic year, there was an out-of-proportion enrolment in the faculty. This was due to the double intake of 1990 of the previous 7-4-2-3 and 8-4-4 systems of education in Moi University. This also saw a rapid growth in female student enrolment in the faculty. However, the highest female enrolment in the faculty was in 1989/90 academic year when $36.01 \%$ of the total B.Ed (Arts) student enrolment in the faculty was female. In 1993/94 academic year, female representation was lowest with $28.1 \%$ of the student enrolment in the education science category. The 1994/95 academic year revealed an almost at par picture between the female students in B.Ed Science and Arts. In 1995/96 academic year female students depicted a lower enrolment $(31.34 \%)$ in education science than the B.Ed Arts category (33.35\%). All the same, the number of male students in both arts and science was much higher than that of the female students. Although teaching is supposed to be a popular profession among the female students, these statistics clearly show that for a long time to come, the 
number of women science teachers in the country will continue to be small. This has an adverse effect on science education for girls in two ways. First, the majority of teachers teaching science and mathematics at the secondary school level will continue to be male teachers who have little patience with the girls and whose attitudes towards the ability of girls to learn sciences and mathematics is negative (Eshiwani, 1983). Secondly, as long as the girls do not see and interact with women science teachers, they will feel that science is not for women. Role models in the sciences is needed to encourage more girls, particularly from rural setups to pursue science subjects.

\section{Gender Representation in the Faculty of Science}

Essentially, this study is about gender access to university education in Kenya. It is therefore important to see how gender is represented at the Faculty of Science in Moi University. This study will be a pointer to the position of over related fields. The data collected for this study show that women enrolment dropped from $8.9 \%$ in $1987 / 88$ academic year to $6.85 \%$ in $1989 / 90$ academic year. Of particular significance and worth noting was the 1993/94, 94/95 and 95/96 academic years which recorded progressive increases in female student enrolments studying science. The female student numbers rose from 17 in 1989/90 to 228 in 1995/96. There are many reasons that can explain this trend. First, the 1993/94, 94/95 and 95/96 academic years comprised the 8-44 system of education students. This system lays more emphasis on science combinations and this might have resulted into more women enrolling in science based courses.

Second, the vice-chancellors Committee discriminative admission policy (affirmative action) of two points lower for the girls might have contributed to this rise. The $28 \%$ of female student (highest so far) in sciences is still low compared to their male counterparts.

\section{Gender Representation in the Faculty of Technology}

The highest number of women students to enrol in this faculty was 21 in 1994/95 academic year forming 6.38\% of the total enrolment in technology that year. This is expected since one of the admission requirements into this faculty is a good grade in Mathematics and this has affected number of girls enrolled in the faculty.

\section{Gender Representation in the Faculty of Forestry Resources and Wildlife Management}

The similar pattern of enrolment in the Faculty of Technology is to be found in this faculty. The female enrolment pattern in this faculty was found to be quite low. In 1989/90 academic year, female enrolment was the highest at $13.4 \%$ and the lowest was in 1993/94 academic year with $10.1 \%$. It is the hope of the researcher that this pattern should change now that other departments have started in the faculty however, it was interesting to note that of the 100 students registered in the department of tourism, only $13 \%$ were female students. This is the faculty with low female enrolment after the faculty of technology. One of the reasons for this low enrolment is the lack of women candidates with better grades in mathematics.

\section{Gender Representation in the Faculty of Information Sciences}

Perhaps, this is the only faculty with an almost progressive female student enrolment throughout the years since its inception in 1988/89 academic year. The female student enrolment ranged between 22.15\% in 1989/90 academic year to $27.5 \%$ in $1993 / 94$. This figure is still low in reaching parity in enrolment. More efforts need to be put in place to increase enrolment at the faculty.

\section{Gender Representation in the Faculty of Social Cultural and Development Studies}

This is the second largest faculty at Moi University in terms of student's enrolment after the Faculty of Education. The Faculty of Social Cultural and Development Studies (SCDS) began two years after the establishment of the Faculty of Education in Moi University. It consists of Departments such as Management Studies, Economics, Geography, History, Religion, Philosophy and English. The Faculty of Social Cultural and Development Studies is similar in many respects to Bachelor of Arts in the University of Nairobi. The Faculty of Social Cultural and Development Studies have shown steady female student progression from $1989 / 90$ academic year at $23 \%$ to $35.53 \%$ in $1995 / 96$ academic year. This is the faculty with the highest female student enrolment skewed towards Arts subjects. This means that the 8-4-4 system of education has, to some extent, plunged the female students to Arts cluster of subjects. 


\section{Gender Representation at the Faculty of Health Sciences}

This Faculty is different from the conventional medical school at the University of Nairobi in that it has a community approach to health. It is more concerned with preventive measures than curative. The graduates from this faculty are mainly concerned with working among a rural population. It is therefore interesting to see how gender is represented at this level. Female enrolment at this faculty will lead to role models in society hence have an effect on the girls education in their areas of posting. The years under consideration here were 1993/94, $94 / 95$ and $95 / 96$. The year $1994 / 95$ had the lowest female student enrolment of $15.25 \%$ compared to $19.0 \%$ in 1993/94 and 19.64\% in 1995/96 academic years. This shows that female students are better represented here than in the Faculty of Technology and Forestry Resources and Wildlife Management. However, this is still a low enrolment and needs to be boosted in order to be at parity with their male counterparts.

\section{Gender Representation in the Faculty of Law}

This is the latest faculty to be established at Moi University. The students in the faculty in the currents academic year (1995/96) are the first batch. This course is still marketable in Kenya today and graduates of this course form good role models for the younger girls in schools. The male students are 30 forming $78.95 \%$ while female students are 8 forming 21.05 per cent. At least this is not bad for a beginning. It is the hope of the researcher that as years progress, female enrolments shall also increase in order to be at parity with the male students.

The female student enrolment was quite low in the beginning years of Moi University. But as years went by, the female student enrolment has continued to improve. For example in 1987/88 academic year, the female student enrolment was 18.74 percent and in 1989/90 academic year, the enrolment was $25.59 \%$. In the years that followed, that is 1993/94, 1994/95 and 1995/96, the enrolment was 28.55, 28.35 and 29.36 percent respectively.

\section{Discussion}

Total female student population during the 1995/96 academic year at the undergraduate level in Moi University was $32.7 \%$ only. This leaves male students with a representation of over $60 \%$. Such a trend was similar in gender representation in most arts based courses. But in the science based courses female students were underpresented by big margins for example in the Faculties of Technology, Forestry and Wildlife Management and Health Sciences. Faculties of Information Sciences and Science (B.Sc.) were fair because they had over $20 \%$ of female students forming the enrolment. The highest female enrolment to be recorded was in $1989 / 90$ in Education Arts where 36.0\% were female and 1995/96 academic year in the Faculty of Social Cultural and Development Studies where female students formed 35.53\%. This information shows that women are dramatically under-presented in Moi University. This finding concurs with the findings of Hughes and Mwiria (1988).

\section{Conclusion}

Gender representation in this study revealed that female student enrolment at Moi University is quite low compared to male enrolment. The most affected faculties are Technology and Forestry Resources and Wildlife Management because the highest female enrolment at one time was $13.4 \%$ for Forestry and Wildlife Management and $6.38 \%$ for Technology. Other Science based courses had at least more than $20 \%$ of the female student representation. Even in the arts based faculties, parity is far from being achieved. This calls for concerted efforts to increase the female student enrolment at the university because of the benefits that come along with this level of education. This study on gender suggests that as far as Moi university enrolment is concerned, the equity objective in higher education has not been achieved.

The following recommendations are therefore made from the study:

a) All universities and other institutions of higher learning should establish a "data base" for all entering students. This will help in monitoring the kind of students that enter the institutions of higher learning and also assist in identifying needy students who need assistance of any form, from the institutions of higher learning, Higher Education Loans Board (HELB), bursary donor agencies etc.

b) A more abrasive government backed affirmative action should be reinforced to bring more girls to university. 


\section{References}

[1]. UNICEF (1984.) Situational analysis of women and children in Kenya UNICEF eastern Africa regional Office, Nairobi.

[2]. WorldBank (1982). Distribution of primary enrolment in eastern Africa. The WorldBank, Washington D.C.

[3]. Husen, T, (1967). Higher education and social stratification an international comparative study. Paris: Unesco.

[4]. Indian council of social science research (I.C.S.S.R) (1975) Status of Woman in India. A synopsis of the Report of the national committee on the status of Women. In Jayaran (1987).higher Education a status retention .student in a metropolis, New Delhi.

[5]. Kerlinger, F. N. (1973) Educations of behavioural research . New Delhi: Holt, Rinehart and Winston.

[6]. UNESCO (1988) International year book of education.vol xl 1969, education in the world Paris: UNESCO.

[7]. Obura, A. (1986). Learning the Gender bias early: Primary School Textbooks. CERES FAO Review, 19(3)456477.

[8]. Maliyakono, T. L., Ishum), A.G.M., wools, S.J. (1982) higher education and development in eastern Africa. Nairobi: Heinemann.

[9]. Graham -brown. (1991). Education in the developing world: conflict and crisis. London: Longman.

[10].Mwiria, K. (1986). The Kenya harambee school movement: a historical perspective, unpublished

[11].doctoral Dissertation, Stanford University, California.

[12]. Nyinge, D, M. (1986). Equity in enrolment by gender and administrative divisions: study of primary school in Kirinyaga district, Kenya (1989-1993), unpublished M.Phil. Thesis Moi university Eldoret.

[13].Kinyanjui, D. (1981). Education and inequality in Kenya, some research experience and issues .IDS working paper no. 373. University of Nairobi, Nairobi.

[14]. Brokencha, D. (1973). The mbeere of central Kenya. In Hughes R .R. and mwiria K. (1988) Kenya. Women higher educational research, Kenyatta University, Nairobi.

[15].Ponsi, F. T. (1986). Sex-and Birth-order selective under-enrollment in the primary schools of Kenya's arid and semi-arid Districts and the 'KEPYIONG', Phenomenon. IDS Working paper No.452, University of Nairobi, Nairobi. 